\title{
EMMA AND PHEBE: "WEAVERS OF THE BORDER"
}

\author{
TOEOLESULUSULU DAMON SALESA \\ University of Auckland
}
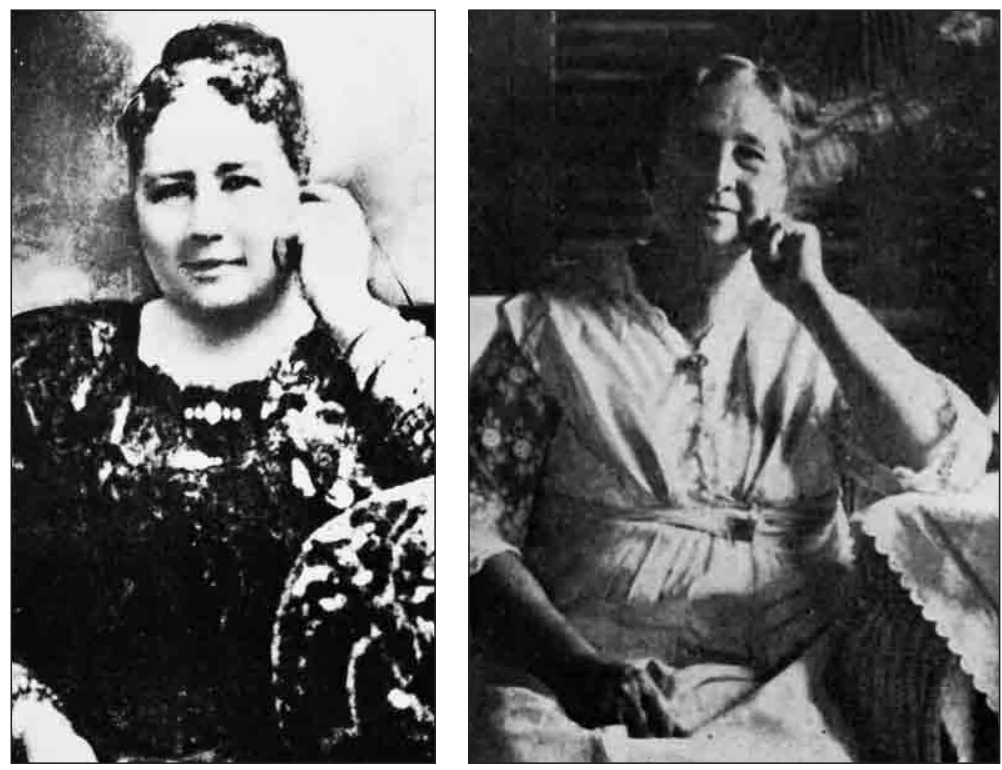

Figure 1. Studio photograph of Queen Emma taken about 1894.

Figure 2. Mrs Parkinson today (probably 1930s).

Few Polynesian sisters have led lives quite as remarkable as Emma Coe (18501913) and Phebe Coe (1863-1944). Born in Samoa to an American father and a Samoan mother, raised in Samoa, the sisters went on to live much of their lives in Melanesia - mostly in northern New Guinea — where they had lasting impact in business, society and settlement. Polynesian women in Melanesia, women in realms that were almost exclusively male, of mixed ancestry in a time seemingly obsessed with purity, there was much about them and their lives that was truly extraordinary. Little wonder that they both achieved levels of fame or notoriety. Phebe achieved local prominence: becoming known in northern New Guinea as "Miti", a linguist, collector, cultural broker, trader and planter. Emma was famous throughout the region: perhaps the most prominent woman in Melanesia of her time, becoming famed (or notorious) 
as "Queen Emma", a wealthy businesswoman and planter, who developed an exclusive and powerful social circle, and shaped enterprise and government.

From the 1880s until their deaths, many foreigners who visited northern New Guinea heard of, or met, Emma and Phebe. Their public personas of Queen Emma and Miti reveal much about the gendered and racialised worlds the two sisters inhabited. Among European and colonial women of their time it was expected that women would make their lives in domestic and private realms; both Phebe and Emma ventured far beyond, making lives in public and commercial arenas, and doing so with prominence. They were women whose ancestry and skin marked them as different, as being unlike both "Europeans"-in whose company they made their money and reputation - while also being unlike the "natives"- whether in Samoa or New Guinea - upon whose lands and labour their wealth and position depended. If their lives were partly about coming to advantageous terms with these complexities, their public personas were about reducing this complexity to simple terms digestible in a time when their achievements ran in the face of so much expectation.

Prevailing colonial understandings about respectability and whiteness appeared to exclude the sisters, so it was remarkable that Phebe and Emma managed - largely through their own efforts - to make claims on both. By the turn of the 20th century, Emma's central position in the developing colonial society of New Guinea, and Phebe's place as an important nexus for commercial and ethnographic knowledge, appeared to have secured not only wealth and advantage, but both respectability and "whiteness". Visiting observers had little trouble in describing them with respectable and inclusive terms, and for most the sisters' claim on being "ladies"- a position not only of gender, but of race and class - was relatively secure. But sitting underneath this apparent security were deeper insecurities made fertile by the sisters' differences. Commerce posed risks for women whose reputations were supposed to be built on domestic and family grounds; and respectability was not something that could be simply purchased, even with the wealth and social accoutrements the sisters could command. Phebe would learn just how fickle these things might prove. Ladies they may have become, but usually in a modified or contingent way- "half-caste Samoan ladies" (Cayley-Webster 1898: 75).

\section{THE EARLY LIVES OF SISTERS}

Emma Eliza Coe was born in Apia in Samoa on 26 September 1850. She was her parents' second child, and was a teenager by the time her youngest sister was born. That youngest sister, Phebe Clotilda Coe, was the last of eight children and was born on 5 June 1863. These two Coe sisters were 
both children of the mixed community at Apia, "the Beach" as it was called, a community made up of foreigners from throughout the Pacific and the world, as well as Samoans from neighbouring villages and the rest of Samoa. Apia changed considerably in the 13 years between their births. It had grown into a commercial entrepôt, with a number of shore traders and some major regional business concerns. When Emma was born in 1850 the foreshore of Apia Harbour was dotted mainly with Samoan villages; by the time Phebe was born much of it, from Sogi in the west to Matautu in the east (where the Coes lived), had been occupied. It was an innovated community, built out of Samoan ways and materials and the things that came over the sea in ships. Some of the neighbours were Samoans, living in traditional fale 'houses'; another was the notorious seaman "Bully" Hayes (Westbrook MS-Papers-0061-072). The sisters were born into a Samoa at a time where a distinctive kind of change was fast occurring, at the place where it was most intense (Gilson 1970: 162-87, Salesa 1997: Ch. 3).

The Coe sisters' early lives were dominated by their 'aiga, their families. Both their mother and father came from families with some wealth and status, though of very different kinds. Their mother, Leutu (Joanna or Ioana) Taletale, was a cousin of Malietoa Laupepa, who from mid-century onwards became a key figure in Samoan politics (for a time, 1881-87, recognised as "King" of Samoa). The family to which Laupepa belonged, Sā Malietoa, was one of the great ancestral lineages of Samoa in the 19th century (Krämer 1994 [1]: 310-21). The sisters' American father was Jonas Myndersse Coe. Jonas was living in Samoa from at least $1846 .{ }^{1} \mathrm{He}$ then began a prominent career on the fringes of a burgeoning Apia, as trader, small scale planter, sometime foreign official and all round opportunist. Both parents were able to provide advantages that were not shared by most of the children of Apia or Samoa, which put the sisters in a position unusual at the time.

Jonas and Ioana had eight children together. The eldest was Maria Miller, then there was Emma, followed by Edward Henry, Mary Ann (who died as a toddler), William Pritchard, John, Ann Murray (who died as an infant), with the youngest being Phebe. In addition to these eight were the children Jonas had with two other mothers. Of these half-brothers and -sisters, there were at least another ten. ${ }^{2}$ After discovering his involvement with another woman, Ioana left Jonas while she was pregnant with Phebe, returning to her family at Falealili. But Phebe's older brother was sent to bring her back to Apia before she was in her teens. There, Jonas' second wife did not treat Phebe well, and while she counted her half sisters as her "true sisters", she longed to be with her mother rather than with "that other family" (Mead and Parkinson, MS. 26 June 1929: 3). In Phebe's account Jonas was also very severe, imposing strict rules, manners and habits, and keeping a very 
orderly house (a bungalow imported from the United States). The return of her older sister Emma from overseas made a huge difference in Phebe's life. "I used to sit beside [Emma] and watch every little thing she did", Phebe later remembered, "I loved her very much and... I was very lonely without her" (Mead and Parkinson, MS. 4 July 1929: 1).

In Apia, as in other colonies, respectable papālagi men went to great lengths to try to secure advantage and opportunity for their children and families. The frontier imperialism of Samoa foreshadowed the deep inequalities of colonialism, and instructed how vulnerable some Samoan claims might be in the face of imperial or colonial interventions. At stake were more than just appearances: it was about the very real benefits that accompanied recognition as a foreigner. With United States citizenship, for instance, concrete rights and benefits could be coherently transmitted. These benefits ranged from the ownership of property, rights of residence and protection, to formal connections to government and state that were denied non-citizens. But these benefits were bound up in ideas about race, civilisation and culture, and were not thought of as separate. Jonas made great efforts to secure both the letter and the spirit of these benefits for his children, and to position them advantageously in the elite foreign circles of Apia. $\mathrm{He}$ wished his children to speak English (as well as Samoan), to dress according to middle-class American norms and to conform to American mores. His children were not allowed to attend parties with mixed race couples, unless they had been officially married. It was a severe upbringing according to their "father's set of narrow rigid standards", where a very different kind of life - a wholly Samoan life - could essentially be seen from the window (Parkinson and Mead, MS. 28 June 1929: 9). Jonas made it clear he did not want his children to marry Samoans. Phebe remembered him saying to Samoans who asked after her and her sisters "what do you think that I take all this trouble to bring up my children and then let them marry Samoans and become Samoans again" (Mead and Parkinson, MS. 26 June 1929: 4).

Jonas made great efforts to secure respectability and connection for his children through education. All of the Coe children were educated in ways that enhanced their ability to secure papālagi culture, language, connection and advantage. Most children in Samoa were going to schools run by "native teachers" trained by European missionaries or in mission institutes. This schooling was largely integrated into village life, and taught in Samoan, not English. These were not the kinds of schools that did the work Jonas desired: the Coe children were educated away from Samoans, Samoan village schools and their limited missionary curriculum. The Coe children also avoided the dominant missionary influence in Samoa, the London Missionary Society, even though they provided schools specifically for white and half-caste 
children (Salesa 1997: Ch. 2). Emma's schooling was given instead to the new Catholic convent at Apia, though neither mother nor father were Catholic. Emma was then sent overseas for schooling, a privilege reserved for very few local children - mostly the children of papālagi missionaries and highranking officials. Emma attended school at the Subiaco Convent in Parramatta, Sydney (from 1860 to 1864), and then went on to school in San Francisco (about 1864 to 1869). Younger sister Phebe had a Catholic education too, though hers was entirely at the local convent - after which she remained a lifelong Catholic (Mead 1960: 186). Emma's education was a measure of just how substantial and defining such educational opportunities might be, and these shaped not only her abilities and her potential, but her sentiments, tastes and ambitions. While still at high school Emma had seen more of the world than almost any other Samoan young person.

The world the sisters inhabited was not just culturally rich, but socially complex. Much as their father desired them to be removed from (and imagined they would be above) a Samoan milieu, as young people they desired to be part of it. When they spent time with their mother or when their father was working they would often break their father's strictures, dressing in 'ie lavalava 'Samoan-style wrap-around dress', putting flowers in their hair, swimming and spending time with their Samoan relatives, imagining themselves like other Samoan young people. Once, inspired by the Samoan examples around her, Phebe even gave herself a home-made tattoo on her legs, using needles and charcoal, like the malu 'women's tattoo from the knee to upper thigh'. Her father later discovered the tattoo when she was recovering from an injury: "Oh, he was wild. He said if you were not sick with that foot you would have a horse whipping" (Parkinson and Mead, MS. 4 July 1929: 1). But exclusivity sometimes ran both ways. "Samoans are very proud and look down on the halfe [sic] castes too", Phebe recalled. She remembered times when Samoans had snubbed half-castes, refusing to consider them for high ranking titles: "They said, what give our high Samoan name to someone who has European blood, and is not even a pure Samoan" (Parkinson and Mead, MS. 26 June 1929: 4). Both sisters seemed to share a kind of life choice that Phebe later described: "I decided to stay on [with my father] and learn European ways and marry as my father wished" (Parkinson and Mead, MS. 26 June 1929: 4).

Indeed, not long after Emma had returned from San Francisco, in October 1869, she married James Forsayth. Forsayth was a 22-year-old trader who had come from New Zealand and owned his own schooner. Emma's marriage to a respectable papālagi secured many things valued in Emma's upbringing, and the marriage was duly recorded in official records. (Jonas Coe was at that time the American representative or "Commercial Agent" at Apia.) Marriages served as public tokens of intimate arrangements, and for foreign governments 
were a key moment when government and law defined peoples' domestic lives. As a woman, foreign citizenship or subjecthood was established or endorsed through a husband, and benefits extended to both wives and, potentially, children. Official marriages legitimated not only a relationship, but also a spouse and children, bringing them within the vision of the state, and in many ways governing their property and even their selves. Emma's marriage was more than just this, of course, and soon thereafter Emma was pregnant, with a girl, Amy, who did not live long. Later, in 1872, she gave birth to her oldest son. He was named Jonas Myndersse Coe Forsayth after his maternal grandfather. ${ }^{3}$

Phebe was only seven when Emma married, and Samoa at the time-Apia in particular - was teetering on the edge of conflict. Part of this was a familiar Samoan tension, between the great Samoan lineages; but foreign ambitions and interference had grown these tensions to dangerous levels. Spending a few months in Samoa seemed to inflate papālagi ambition, and simultaneously decay their judgement and sense of proportion. The empires most interested in Samoa-Germany, Britain and the USA - each wanted a Samoan leadership that favoured them and their own interests. Samoan disputes were cultivated and exploited, and foreign interventions destabilised and disrupted Samoan efforts to produce a durable political settlement. Apia was by then a commercial hub. Samoa was a source of coconut oil and the coconut oil industry required land, ships, labour and a harbour. With Apia as its main Pacific base the Hamburg firm, Godeffroy und Sohn, had come to dominate the central Pacific trade. Apia hosted official representatives from each of the interested empires, and warships - the instruments of intervention-visited periodically. By the 1870s a complex tragedy of foreign interventions and Samoan political rivalries was underway which was to last 30 years.

This Samoan and imperial political drama is not easy to describe compactly: but it was a drama with which the Coe family was intimately connected. The first connection was through the Coe's Malietoa relations, 'aiga to Emma and Phebe through their mother. In a key period that both the girls experienced, the Sā Malietoa 'the Malietoa lineage' was itself in conflict, as rival successors (Talavou and Laupepa) went to war to cement their claim (1869-72). The second connection was through Jonas and Emma's personal relations with a "Special Agent" sent out from the United States, Colonel Albert Steinberger. Jonas became involved with Steinberger politically; Emma was involved with him intimately (her husband, James Forsayth had earlier died). After his initial visit Steinberger wrote a report, and then went back to the US. Emma remained a correspondent of Steinberger's, and soon after went on to spend time with him in the US. When Steinberger returned to Samoa in 1875 , he was appointed as Premier by Malietoa Laupepa's 
Samoan government, but this elevation had rested on an intricate complex of double dealings, particularly among German and American commercial and political interests. ${ }^{4}$ Emma and Jonas had closely associated themselves with Steinberger, and this association was soon risky. Steinberger lasted less than a year as Premier, before an alliance of foreigners pressured Malietoa Laupepa to arrest him. Joining him in lockup was Jonas, and both were deported by a British warship to Fiji, then New Zealand.

Jonas was soon back, but Steinberger never returned. The troubles in Samoa had seen an increase in land sales, more foreign interventions and increasing instability. Jonas had himself played a part in this, successfully finding opportunity in this time of upheaval and war. Phebe recalled how "my father gave the chiefs ammunition and guns and then when they could not pay they had to give him their lands" (Mead and Parkinson, MS. 26 June 1929: 3). It was an unfortunately common practice, and proved profitable. But, as Jonas' deportation had taught him, the war also had deep costs. Not least was stability, as rumours seemed to have Samoa being annexed by the United States one week, Britain or Germany the next. Malietoa Laupepa's complicity with Steinberger's removal had forced him to retire from Apia, his influence in retreat. Apia trade was increasingly cornered by the huge firm of Godeffroys, and the US star that seemed to rise with Steinberger, now sat much lower. It was at this juncture that Emma left Apia, and soon after left Samoa. Emma left with the Australian Thomas Farrell, who would be her new domestic and business partner.

\section{THE LADIES AS COLONISERS.}

By the time Emma arrived to settle at Mioko, on the Duke of York Islands off the coast of New Guinea, she had become the common law wife of Thomas Farrell. Farrell was an Australian sailor, trader and entrepreneur, and together they began as traders for the Apia-based Goddefroy und Sohn, but very soon they set up their own trading enterprise. They both already knew that island trading could be a lucrative business, though it was risky and difficult work. Farrell brought not only important trading and sailing experience to his partnership with Emma, but also a poor reputation (see for example, Danks 1933: 123-24, 155, 157-58). Farrell was accused of leaving traders ill-equipped and with little support, and of keeping his traders in debt to him. One trader described how Farrell went even further, and forced him and his father to sign on at "the point of a revolver, we [were] threatened by a man who was not better than a pirate" (Mouton 1974: 70).

Both Farrell and Emma proved not only to be entrepreneurs, but opportunists. The most bizarre of these opportunities came after a disastrous plan to form a colony of settlement on the island of New Ireland, an island 
neighbouring Farrell and Emma's main base on New Britain. The brainchild of Charles Bonaventure du Breuil, a French nobleman who styled himself the Marquis de Rays, du Breuil inspired - or perhaps more accurately, deludedinvestors and colonists into supporting his plans for a New France on New Ireland (Niau 1936). ${ }^{5}$ Between 1879 and 1881 over 700 people emigrated from France, Italy, Germany and Belgium to the first colony at Port Breton (the renamed Port Praslin). About one half died on the voyage out or soon after they arrived. Even hefty financial backing could not rescue the plans. The unfortunate survivors were starving and malarial, left to struggle on without the "wisdom" of the Marquis de Rays, who had stayed in Europe. Everywhere the plans reeked of a European short-sightedness: the site of settlement was poorly chosen, the settlers were inappropriately equipped - there were over 100,000 bricks for a cathedral and hundreds of dogs' collars, while medical supplies were inadequate. The settlers were thrown at the mercy of the elements, the local communities, and the missionaries and traders in the region.

By February 1882 the last 40 colonists remaining at Port Breton were helped off by Thomas Farrell. Thomas and Emma negotiated with the colonists and funded their evacuation in exchange for goods and one of the steamships. There is a story that as the ship came into harbour near Ralum, the starving and ill colonists could hear Emma at the piano playing "The Blue Danube" (Niau 1936: 157). Only a dozen of these survivors stayed on in New Guinea (some going to work for the Farrells) while about 200 went on to New South Wales and Queensland. The Farrells showed decency in giving aid to the pitiful colonists, but the vessel and goods they gained moderated any claim of altruism. This ambivalence was noticed by a later visitor to their house, who observed the cannon taken from the settlement out front and one of New France's flags flying on the verandah. Inside the dining room was the colony's altar, which had supposedly been consecrated by the Archbishop of Milan. "It was a magnificent work of art, beautifully inlaid... used for the purposes of a sideboard, and was stocked with wines and spirits" (Rannie 1912: 284). Yet even this brashness paled beside rumours that Thomas and Emma had poisoned one of New France's autocratic - and possibly crazed-leaders. ${ }^{6}$

Sister Phebe arrived in New Guinea as the de Rays' debacle was mostly played out. She had recently married Richard Parkinson, a much older German, in a marriage her father approved but which she had been unsure of. Their mother, Ioana, had moved in with Phebe, as had Emma's son Coe Forsayth and a number of 'aiga. Richard was keen to move to New Guineahe was a naturalist and ethnographer and imagined riches of that kind-but Phebe needed persuading. The bond between sisters won out: “. . it was only because I loved [Emma] so that my husband and Farrel[1] succeeded in 
persuading me to come up here [to New Guinea]. That was the root of their winning" (Mead and Parkinson, MS. 4 July 1929: 1). The Parkinsons did not travel alone. Phebe had already had her first child, and she also brought her mother, as well as a large proportion of their household. Polynesians abroad, these Samoans were effectively colonists.

Emma and Thomas Farrell had secured an important foothold on the Gazelle Peninsula in New Britain and had started building their headquarters at Ralum. With Phebe and Richard's arrival it was obvious how the domestic and personal were intimately connected. Thomas died a few years after Phebe arrived, in 1886, and Emma returned to her previous name of Emma Forsayth, and the business changed name to E.E. Forsayth \& Co. By this time it was already a substantial enterprise, with trading posts and plantations throughout German New Guinea and even a few beyond. Ralum was the centre of all this; "a splendid plantation" run entirely by Mrs Forsayth. In the context of the times, such achievements, by a woman and not a white one at that, often stunned onlookers: "She does all the correspondence, keeps the accounts, and personally superintends the work of the plantation. Of course she still has a manager... but she still believes in having an eye over all" (Pitcairn 1891: 172, 184). As one English gentlemen remarked upon meeting her:

In these days of militant feminism, it is interesting to bring before the readers of these pages the fact that here in these remote regions a woman's tact, skill, capacity and endurance have achieved commercially, more than any of her masculine fellow-traders. (Pullen-Burry 1909: 110)

E.E. Forsayth \& Co. would be a major force in the region for nearly a quarter of a century.

About this time Emma was becoming known, increasingly, as "Queen Emma". Not only was Emma a commercial power, the name seemed appropriate for such a "handsome and very striking figure" whose "whole carriage was queenly" (Rannie 1912: 283). The name stuck. Her business acumen had made the business breathtakingly successful. "As a business woman," one settler observed, "she was as keen as a razor" (Hansen 1925: 1). Meantime Phebe was forging her own public character. She was becoming known as "Miti", Pidgin English for Mrs, and had learned useful local languages (including both German and some Kuanua, the language of the Tolai).

The arrival of the Parkinsons signalled the beginning of an expansionist phase of what was to be Queen Emma's realm. Richard Parkinson was destined to become a well known botanist and ethnographer, and his expertise in tropical agriculture was a boost to Queen Emma's coconut planting programme, which in 1882-83 was the first sustained effort in the 
northern New Guinea region. ${ }^{7}$ Meantime Phebe was proving herself a capable plantation manager and an able recruiter of local labour. Richard and Emma set about buying land, and huge tracts were "acquired"-often in ways that were questionable (Pullen-Burry 1909: 115-16). Richard's endeavours "laid the foundation of Emma's wealth. He bought hundreds of acres of land from the natives for a mere song and planted coconuts, cotton, [and] broom corn" (Goedicke 1952: 66; see also 1941: 39). The change was rapid: one onlooker mused in 1898 that in a place where only 20 years before "not a white man could exist", he now "drove in a pony phaeton through [Emma's] plantation alone for four hours without seeing the whole of it" (Maitland Weekly Mercury, 1898). He estimated that the coconut trees numbered in the hundreds of thousands.

The lands were the foundation of the sisters' wealth, but it was wealth that could only be realised if people could be made to work the land cheaply. Emma and Phebe's plantations relied on hundreds of labourers recruited from throughout New Guinea and the Solomons - mostly from Buka and Bougainville. Loss of land, exploitation of local workers, the arrival of so many foreigners, the development of New Ireland into a colonial centre, also weighed deeply on local peoples. Pressure increased further as the plantations continued to expand, encroaching further on the islanders' villages. Despite repeated complaints to German authorities by local islanders, these had little effect, as Emma worked to have her claims recognised by the colonial administration. The outcome for local people was poor. Some Tolai still remember Emma, figuratively, as someone who seduced away Tolai lands asserting: “... that both Queen Emma and the big men prostituted themselves - the former by selling her body, the latter by selling their land" (Neumann 1992: 232).

Phebe was emerging as a key element in her sister's plantation business. Her husband went to work for others, and to start a plantation of their own, but Emma asked Phebe to stay on as plantation manager. Phebe had already established strong links with local leaders and communities. Since her arrival she had shown herself able to handle the many challenges of planting and securing workers.

In the early days [1883-4] I used to take my baby and go up into the bush on Sunday[s]. I had to take Nellie [her second daughter, Helene] because she was a baby still at the breast. But I had to go because I wanted to see how the natives lived. I took a boy to carry the baby and six boys with Snyder rifles and I took my Winchester and so we went up.... I used to come back laden with presents of sugar cane and taros. Later that was very helpful to my husband when we had trouble with the natives or he wanted to find a special native, he would ask... and then I would tell him. (Parkinson and Mead, MS. 3 July 1929) 
This was Phebe's approach, and was a major reason why so many people thought her remarkable. While not excepted from the kind of racial thinking then pervasive about Melanesians, Phebe had an unusual willingess to live and work with, and to respect local peoples, and an unusual interest in what these peoples thought, said and did.

By the 1890s Phebe had an established reputation as a cultural expert, artefact collector, advisor and translator in northern New Guinea. The research for Richard Parkinson's (1907) enormously successful book, Dreßig Jahre in der Südsee (Thirty Years in the South Seas) hinged on Phebe as she could speak Pidgin (Richard could not) and had some facility in other local

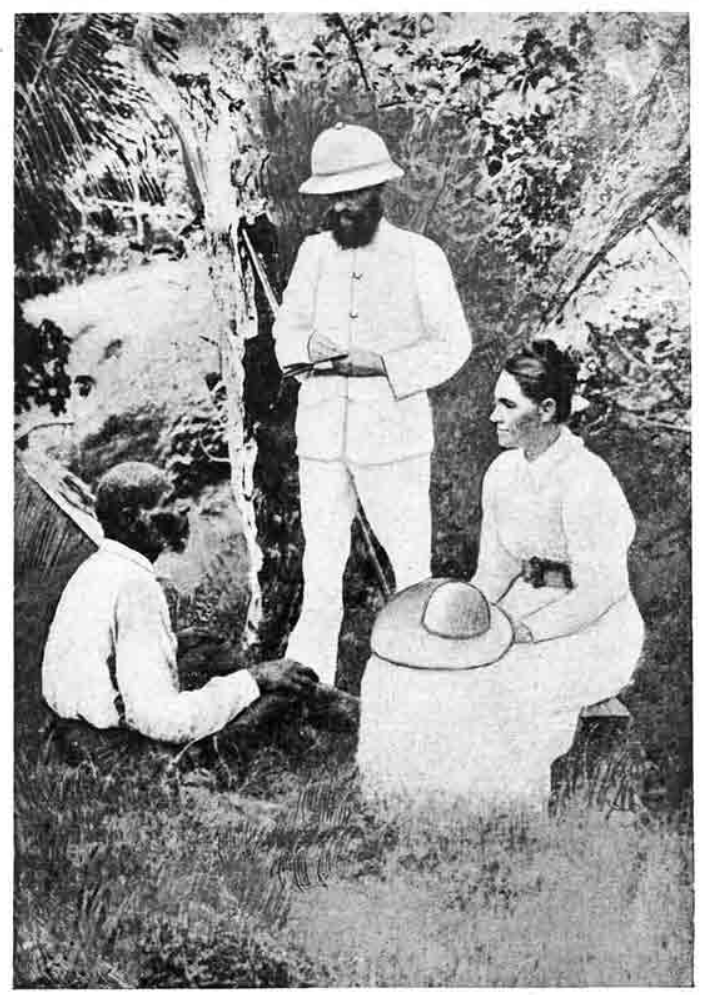

MRS. PARKINSON TRANSLATES THE OLD CANNIBAL'S STORY FOR HER HUSBAND

Figure 3. 
languages. Visiting anthropologists, travellers and voyagers also had Phebe show them around. Margaret Mead even used Phebe (controversially) as an informant on Samoan society, though she had been away from Samoa for over 40 years, and had spent very little time in Samoan villages when she was there (Freeman 1983: 251-52; but compare, Mead 1977: 62; Overell 1923: 44; Pullen-Burry 1909: 48, 84, 89-90).

The kind of cultural and knowledge work that Phebe did dovetailed with her work as a labour recruiter and plantation manager. Her husband Richard was enormously interested in the natural and cultural worlds that surrounded them, but by the later 1890s was increasingly unwell and weak, and dependent on Phebe for the legwork and cultural and linguistic expertise that made his scholarly work possible. Richard had become well known as a collector of New Guinea material culture, and had gathered an impressive network of correspondents, dealers and museums. But much of the labour behind this was Phebe's. She combined recruiting trips with collecting, and seemed to gear her collecting to the market, whereas her husband used collection more to cement his reputation as a scientist. (Richard had earlier sold thousands of objects to museums in partnership with the profit-driven Thomas Farrell). Phebe carefully selected and described pieces, and they are to be found in museums throughout Australasia, Europe and America, from Sydney to Leipzig to Oxford (Knowles, Gosden and Lienert 2000: 43-44). Phebe received little recognition of her work, largely because she did not pen the correspondence-Richard "did not acknowledge the contributions of his wife" (Specht 2000: 29). This was par for the course at the time, when women's contribution in traditional male spheres was often hidden or unacknowledged. But as Phebe's work after her husband's death was to show, she was perfectly able to collect and circulate artefacts on her own.

Emma's work was far more obvious than Phebe's, and nowhere was it more obvious than in the establishment of Queen Emma's "court". As both Emma and the Parkinson's businesses grew wealthy, the social orbit that revolved around Ralum became more opulent. In its context the homestead at Gunantambu, a half mile buggy ride from the warehouses and offices at Ralum, was palatial. Family gatherings with friends at Gunantambu transmutated into "society". One observer was enchanted:

the neatly-trimmed lawns and summer house compare favourably with pleasure-gardens of the kind in Europe. Here Queen Emma presided over her little court, and very smart were some of the gay muslins worn by the planters' wives... whilst the gentlemen present were clad in those white suits which are so suitable for tropical wear. The programme commenced with the dancing of New Ireland 'boys', who were to be followed by the kanakas of the Gazelle [Peninsula]. (Pullen-Burry 1909: 201-2) 
Foreigners languidly remembered the "songs, both German and English; solos, duets, trios and quartettes". These songs would often by complemented by Samoan music, dance and food (Pitcairn 1891: 172, 184). It was a mannered, even snobbish society, but also a theatre of domination, where island men were "boys", island women were servants, and the privileges of the half-caste Samoan ladies were not only etched onto the land, but into performances and domestic life. The Queen's court was explicitly political and economic - the American consul, for instance, lived within the Gunantambu grounds. The siblings, relatives and offsiders that had been brought from Samoa often cemented relationships with traders or other petty operatives around Emma; an intimate relationship with one of the Queen's companions often implied a relationship in other ways (Mouton 1974: 118n, $135 \&$ n). Both sisters were integral, but it was the elder one that presided as Queen over that "human menagerie" (Pullen-Burry 1909: 201-3).

As might be expected though, not everyone admired or even liked this exclusive and influential social set. Octave Mouton, a Belgian planter and trader, was among those excluded (Biskup 1974: 6). To Mouton it was painfully apparent how the court wielded both political and social influence. After a disagreement with the Farrells he felt that he and his father would not be heard by German naval officers, for the Farrells "explained [the] matter in a different way, together with [a] champagne dinner to wash it [down], [so] there was no chance [for us] to have justice" (Mouton 1974: 75). Others

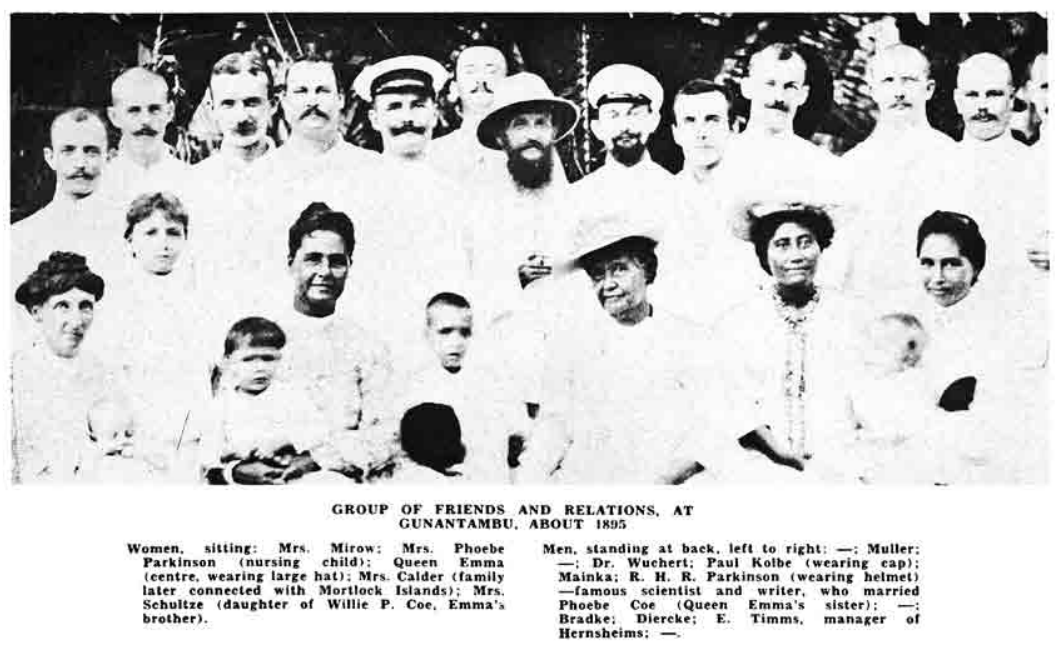

Figure 4. 
were much more acerbic, like Count Rodolphe Festetics De Tolna, who blamed Emma for his run-in with the colonial government and called her his "persecutor". He was not convinced of the suitability of Emma's queenly title. ${ }^{8}$

Phebe was never as comfortable as her sister within this exclusive and influential circle. Phebe was connected and satisfied with local islanders in ways her sister never was, and never quite at ease with Emma's new status and nickname. Emma's house, Phebe commented, "was very near to ours but some times I did not go over there for month" (Mead and Parkinson, MS. 27 June 1929: 7). Phebe explained it partly through her busy-ness, but also through her preference for people and work life. Phebe's home was open to a more diverse group of peoples. She welcomed Melanesian women and children into her home and raised many children who were not her ownmixed race children, and those without a home to go to. Moreover, Phebe had not enjoyed the strictures of respectability for women in society when she had visited Sydney, and it was these mores on which the Queen's court drew. But there was perhaps more. On another occasion, while in Sydney, Phebe discovered that her relatives living in New Guinea were being called "princesses" when they visited Sydney: "Oh, I said, very much disgusted, they are just my niece and my nephew's wife they are no princesses, my sister is no queen, that is just the name which the people give her in the islands because she is good to them all" (Mead and Parkinson, MS. 6 July 1929: 1).

The Ralum court was set within an expanding German empire. The northern side of New Guinea, where Emma and Phebe lived, had become increasingly German, and this culminated in the annexation of northern New Guinea in 1884. For most of the remainder of the century German New Guinea was run by the officially sanctioned New Guinea Company until it was finally replaced in 1899 by a German colonial administration proper. The new administration recognised all of the sisters' key holdings, but presented another kind of challenge. As respectable Germans brought wives and families to live in German New Guinea, they established social spaces that competed and contrasted with the Queen's court. The bungalow at Gunantambu did not remain the unparalleled centre of German New Guinea social life for long. The excesses of Gunantambu deterred the more ascetic of German officials, and they sought company elsewhere, not least at "Raule", the home of the "Sultan of Matupi"(Max Theil), or "Wahlenburg", Rudolf Wahlen's home (Sack and Clark 1980: 47). Many colonials, no doubt, were deterred by the Samoan flavour of the manners and people at Gunantambu.

To local islanders the racial distinctions between the two sisters and other colonisers must have seemed very fine ones. But as colonial domesticity and public life became increasingly German, racial distinctions became more pronounced, and the sisters" positions as "half-caste Samoan ladies" 
more fraught (see as examples, Overell 1923: 51, 55; Pullen-Burry 1909: 109). In the hierarchies of race at the time, the various races of the Pacific were put in particular order: typically with Polynesians assigned a higher place than Melanesians. Race mixing made these hierarchies complex, and Samoan "half-castes", seemingly out of place in New Guinea, complicated things further. Add wealth, gender and respectable marriages, and rigid racial hierarchies appeared more elastic; but, among colonials, race remained potent.

Phebe's son Otto felt the power of race keenly. Chosen by the German governor to organise a celebration of the Kaiser's birthday, German-educated Otto had devotedly gone about his work. But the event did not go as he had planned, and decades later Phebe recalled it clearly. "Many of those present resented it and when [he] offered them drinks [they] insulted him and said 'Who are you to offer us drinks. You are nothing but a half blood, nothing but a kanaka, you are nobody"' (Mead and Parkinson, MS. 4 July 1929: 2). Excluded from a society he felt he belonged to, Otto took drastic steps, leaving his government job and turning to planting. But hierarchies of difference often worked more subtly, more pervasively. Some of Emma's prominence was precisely due to the way that she and her achievements were so unexpected, given racial and gender expectations. One of Emma's visitors could hardly contain their surprise that she was "a half-caste Samoan, and as intelligent and accomplished a woman as any European" (Pitcairn 1891: 164).

As Otto had found, Germans and other colonials were troubled by race mixing, half-castes (mischlinge) and other kinds of inter-racial intimacies. In many ways this might have seemed surprising, for in New Guinea, as elsewhere, German colonials were often involved with local island women. Nati Wahlen was the child of one of these relationships, and lived with her "aunt" Phebe after being educated in Germany. She explained:

My mother was one of [Rudolf Wahlen's] young virgins - all Germans did that, all the colonial white men, and they had to be virgins - it is nothing, why do white men make so much of it? They had to be beautiful as well as virgins. They went to the village chiefs, the luluai or kukurai, and they would buy them, usually two or three at a time.... Those bloody Germans, they had the time of their lives, five or six women feeding them, waiting on them, and the women liked saying they 'belonged to So-and-So Master', and getting the new things. ${ }^{9}$

Herr Wahlen, Phebe remembered, "kept a regular harem" (Mead and Parkinson, MS. 3 July 1929). In terms of quantity Wahlen might have been an extreme example, but such relationships were commonplace, well known and yet rarely public. This was the cutting edge: the racist proprieties of New Guinea's colonial society at once discouraged legitimate marriages between 
Germans and Melanesian women and enabled other - often more exploitativesexual and domestic relations. These kinds of relations were entwined with the lives of Emma and Phebe, firstly because they shaped understandings of women and race, but also because these were relations - concentrated in and around plantations - that were part of the sisters' ordinary world.

In 1893 Queen Emma married for the last time, to Paul Kolbe. Kolbe was German, a former army officer who had been working in New Guinea as a colonial administrator. He was younger than Emma, and some suggested that the marriage was one of convenience: convenient for him owing to unemployment and supposed debt, and convenient for her as she desired both connections with the German establishment, and the respectability afforded by marriage. The two began travelling together. In 1895 Emma went back to Samoa for a visit for three months, staying with her entourage in a hotel on the Beach at Apia. Later in 1902 she returned to San Francisco. In both places, and on her regular trips to Sydney, she was conspicuous. In 1907, at age 57, Emma took a grand tour of Europe. Phebe on the other hand, stayed at home, overlooking the plantations and increasingly caring for her ailing husband.

German annexation in 1899 had not immediately altered the situation where the sisters lived. The same challenges persisted. There were many more locals than European or Samoan settlers, and understandably the locals were not always welcoming. If the settlers had ever forgotten the dangers of being a trader, which was unlikely, a number of events would have served as tragic reminders. John Coe, the first to join Emma in 1879, had been trading for E.E. Forsayth on the outlying island of Nuguria when he was killed by islanders in 1889. The typical response to such a tragedy was the violence of a punitive expedition, and this particular one was flavoured with vengeance. Bloodshed offered little satisfaction, and worse, it was punctuated by the death of Agostino Stalio, who Emma's main biographer believes had been her domestic partner since about 1884.

Colonialism was undergirded and textured with violence. Certainly there were vigorous local cultures of violence, and attacks by one local group on another were common. But plantations, with their combination of land settlement and waged labour proved to be special concentrations of violence. This was especially clear in the Tolai uprisings of 1890-93, as well as in the attack which killed a German planter (Rudolf Wolff) and endangered one of Emma and Phebe's nieces (Neumann 1992: 10-31). Recruitment often precipitated violence, plantation lands were often acquired forcefully, there were disputes between workers and locals and then, of course, there were the plantations' daily brutalities. After Phebe's husband died the German government would send a "judge" to her plantation monthly, specifically to whip any workers who were troublesome. One labourer had tried to break 
into Phebe's room to get to the wives of absent workers. "The Judge had him soundly whipped with leather thongs until he whimpered and said, 'Oh Missus, me like die now"' (Mead and Parkinson, MS. 5 July 1929: 2). Such violence was routine, as routine as Phebe rarely travelling anywhere without "her boys and her Winchester" (Mead and Parkinson, MS. 5 July 1929: 2).

A tragic instance which revealed the depth of their family and business relations, was the suicide of Phebe's son Otto. This was partly over an unpaid debt to his aunt Emma - though it was only a very small one (Overell 1923: 48). It was an extremely painful event (echoed afterward as Phebe's youngest son Franz would also commit suicide). Phebe's daughter Nellie held Emma partly responsible, and "ordered her aunt and her crocodile tears away from the corpse" (Parkinson and Mead, MS. 4 July 1929: 2). The sisters now had much between them, but were bound together still by business and family. But the key anchors in their shared lives, Phebe's work for Emma's company and their aging mother, were coming loose. Their mother Ioana died in 1905, after having long been nursed by Phebe (Mead 1960: 201-2, Parkinson and Mead, MS. 5 July 1929: 3). And Richard and Phebe had begun developing their own plantation, which they moved to about the time that Otto committed suicide - suggesting that the event may have affected relations between the sisters.

Also around this time Emma decided to sell her New Guinea interests and move to Australia. No doubt there were many reasons - her troubled health, the growing German settler presence, her age and changes in the commercial situation, perhaps also the death of Otto. Forsayth \& Co was one of the few large plantation interests left in northern New Guinea that was not German. Emma's son was already spending a large part of his time in Sydney as well. Phebe and Richard, with their large family, settled on a new plantation of their own, at Kuradui, not far from Kokopo but still within comfortable range of Ralum. These big changes soon multiplied. In their first few months at Kuradui, Richard Parkinson died, after a long illness and a buggy accident. Phebe was left on a new plantation, with a large collection of children and a wealthy sister who was just about to leave.

\section{'WHAT WILL BECOME OF THEM?'}

When Emma sold up in 1909, she was perhaps the largest and wealthiest planter in New Guinea. Heinrich Rudolf Wahlen, a German planter and entrepreneur, managed to find the funds by the end of the year and his Hamburgische Südsee Aktiengesellschaft assumed Forsayth \& Co's interests. Emma moved to Mosman in north Sydney, and her health led her again to tour Europe. She was accompanied by her husband, and their European jaunt lasted through most of 1910. By 1911 they were back in Sydney, though 
before long Paul Kolbe returned to Europe. Emma was living in Sydney when she received news that her husband was in some distress in Monte Carlo. Emma arrived to find her husband ill in Monte Carlo, where he died on 19 July 1913. Emma died two days later, on the 21st July. She had been unwell for some time, and the papers gave the cause of her death as "heart failure" (The Argus, 29 July 1913). The leading Sydney newspaper eulogised Queen Emma as "one of the most notable figures in South Sea circles" (Sydney Morning Herald 1913: 16).

Phebe remained in New Guinea. Phebe had refused a generous offer to purchase her plantation along with her sister's. Even after her husband's death she had decided not to join her sister in Sydney. She had been to Australia once and had not liked it (Mead 1960: 203). Phebe was very intimate with the German administration and German officials. She went on walking tours with the governor, and even oversaw the birth of his daughter. Most of her surviving children were still in New Guinea, as were a large number of Phebe's 'aiga including a full brother, several half-sisters, and a large collection of nieces and nephews. She was a busy woman, a 50 year old in 1913, with labour to recruit, plantations to run. Her husband's death was challenging, but the energy and expertise in running the plantation had long come from Phebe. "Everywhere Miti was recognized and glad cries of Miti, Miti resounded" (Overell 1923: 88). It seemed that Phebe had secured both respectability and financial security, despite the obstacles that she faced as a "half-caste Samoan", a woman, and a widow.

The First World War, however, transformed Phebe's fortunes. The War brought the end of the German empire, and within weeks Australia had invaded and occupied the German colony. Phebe was a German widow, and most of the German men and women were deported, including even some of the Samoans. Of all the troubles caused by the War, Lilian Overell wrote as she watched them unfold, the saddest was "the case of the Samoan women". She opined, "Many of the Germans married half-caste Samoans.... What will become of them?" (Overell 1923: 55). Samoan women of New Guinea were excluded from parties, even prevented from holding their own. Phebe's son, who had declared his intent to serve in the German navy, became a pariah. No longer was the administration filled with old friends who knew and respected them. Phebe's place in society was visibly insecure, as she waited to hear if she would be allowed to remain and whether she would be allowed to keep her properties. It was not until 1922, four years after the end of the war, that it was confirmed Phebe could stay. Business had been poor and prices low, and her Kuradui plantation had large debts. Phebe was forced to sell. She moved in with her children, and turned to her languages and wits, finding a living from a large trunk, recruiting labour with "lap-laps and beads and mirrors 
and tomahawks and axes and knives - this was how she bought the boys" (Roberts 1996: 113). Her children were also in danger of losing their own properties, both to the occupying Australians and to creditors. It was tough times for everyone, though Overell thought it "was hardest of all for Miti, a Samoan who knew no other world than the Pacific" (Overell 1923: 150).

The Germans had recognised before the war, as the Australians came to after it, that Phebe-Miti - was someone special, one of the last living pioneers, a kind of living treasure. She reminisced to visitors and held on to papers and photos. Stories gathered about her, and aggregated into images of her as New Guinea pioneer, learning about the natives, but always with an iron fist inside the lace glove. A character in the region's history, Miti was often depicted on a bungalow verandah, with a baby in one hand and a gun in the other (Cayley-Webster 1898: 75-76). In 1921 Phebe entrusted Oliver Bainbridge, who claimed to be a writer, with a large collection of papers and photographs and paid him a substantial amount of money (£100) to write a book about her. He asked for a further $£ 200$ (Bainbridge to Parkinson, MS. 11 January 1921). No book came of it. The Australian colonial judge "Monty" (Later Sir Beaumont) Phillips hoped that this could be rectified if Margaret Mead, the American anthropologist then working in the area, took up and completed the task (Mead 1973: 178). Mead's famous work Coming of Age in Samoa had been published in 1928 and she was already one of the most celebrated women in America. Mead knew Phebe well and was given some materials and promised to share any profits which the book might make. Mead secured a publisher's interest, but in November 1929 Wall Street crashed and the world soon followed. In distant New Guinea the Depression spread through the devastating collapse of copra and agricultural prices. Before the Depression there was only a small market for Phebe's story; afterwards there was effectively none.

Phebe had fallen on extremely hard times. A proud and dignified, yet grounded and resourceful woman, by the 1930s Phebe had not only lost her plantation and husband, but had seen seven of her twelve children die. Phebe was living, with few means, first with her son-in-law, and then with a grandson. Various promises made to her had not been kept. She turned, reluctantly, to Mead, in the hope that either an English translation of her husband's successful book about New Guinea, or the planned book about her, might provide some funds: "... so you see, my dear friend," she wrote to Mead in 1932, there is "no end [to] my sorrows, I don't think I deserved it" (Parkinson to Mead, MS. 21 July 1932). Mead had heard from publishers that the translation would not be profitable and they were not interested, and while a small publisher was interested in a book about Phebe, it seems largely to have been because of Mead's celebrity, and was very far from concrete. 
Mead sent $\$ 200$ of her own money to Phebe which she phrased as an advance on the book (Morrow to Mead 6 August 1931, Mead 1960: 178-79). As she later explained to Phebe's daughter, "I felt it was a great pity that your mother should not enjoy something of the possible proceeds, should the book ever be written" (Mead to Dolly Messenger, MS. 1 October 1947).

Two years later, having seen Mead when she visited Rabaul, things were even harder. Phebe was stuck in the Solomons, unable to even get back to New Britain where she had a home- - "my grandson Rudi \& self are stranded living in a little grass house without a penny" (Parkinson to Mead, MS. 8 January 1934). Mead sent another smaller "advance". Phebe let Mead know that this had allowed them to return to Rabaul, where Rudi had gotten a job (Parkinson to Mead, MS. 28 June 1935). Things had improved but the golden days of Gunantambu and Kuradui were well in the past.

Mead finally did write a short biography, a beautiful and poignant essay published 16 years after Miti's death: "Weaver of the Border" (1960). The editor wanted her to write about a different informant, but Mead was only interested in writing about Phebe. She considered the essay would "finally discharge a kind of moral debt" (Mead to Thayer, MS. 10 March 1958). Mead described Miti as, someone who lived in a "world between", tying together two worlds, native and European - a weaver of the border. It was an apt description (though it contained some errors, including about the date and circumstances of Phebe's death), and captured much that was distinctive about Phebe's life, as well as much that was unique about her person. Phebe the collector of culture, recruiter, translator, a woman in a male-dominated world, a Polynesian in colonial society. It was this kind of work that heightened Mead's empathies for Phebe; much of it was work that paralleled what Mead herself was engaged in.

Phebe's death was obscured by the violence and scale of the Second World War. This time world war came directly to Phebe; the Japanese occupied northern New Guinea, turning Rabaul into their major base in the region. Many settlers had left after the Pearl Harbor and Malay Peninsula attacks, and most of those who remained were evacuated moments ahead of the Japanese landing. But not Phebe, Rudi nor his family, who it seemed had been neither invited nor warned-perhaps owing to their German names and connections (Uechtritz 2003). Though the Japanese occupiers continued to let the Parkinsons live on the New Ireland plantation, the nearby crash landing of an American B-17 changed the situation. Rudi, his family and Phebe were placed in an internment camp at Namatanai on New Ireland. In the hardships of the camp Phebe died on 26 May 1944. News of her sister's death had taken a few days to travel from Monte Carlo to Sydney. News of Phebe's death arrived in Sydney over a year after the event (PIM 1945: 51). 
If Phebe and Emma had then been forgotten, as it often seemed most Polynesian women were, this history might well end with Phebe's death. But the two sisters, especially Emma, had become celebrities in their lives, and their celebrity and significance were enduring. Emma Coe had been noticed before she had become "Queen" Emma, but as the Queen, she was truly famous. "In every corner of the South Seas [Queen Emma's] fame and renown have been the theme of many a captain's gossip, of many a trader's envious encomium" (Pullen-Burry 1909: 110). Forty years after Emma's death Australian newspapers were still writing features about her (Blaikie 1954). In 1965, the journalist Robert Robson published his biography Queen Emma, a self-described "colourful romance" (PIM 1953: 16). Robson worked hard to unearth Emma's life, but he often exaggerated, even "reconstructed" dialogue. For these and other reasons the book is unreliable. It was also written through a colonial prism: fascinated with cannibalism, and framed through patronising and offensive depictions of "natives" (Robson 1965: 92, 96-97, 99, 127-29, 148). Robson built his portrayal of Emma on earlier writers who had defined her, and indeed Polynesian cultures more generally, through a saturating and exotic sexuality. Robson used this sexuality to explain much about Emma's person, her achievements as well as her mother-culture. ${ }^{10}$

Most of the accounts of Emma have likewise been preoccupied with her gender and sexuality, run through with visions of the Polynesian exotic. Robson's book, typifying most posthumous accounts of Emma, is devotedly prurient. For those familiar with the deep genealogies of the European sexualisation of Polynesia, the rendering of it as exotic and erotic, this is hardly surprising. Nor is it surprising that such imagery might be retransmitted in representation after representation, heavily guided and sourced from a few earlier and flawed versions of her story. A. Grove-Day's biographical essay on Queen Emma, for instance, was largely a condensate of Robson (GroveDay 1969: 82-122). The numerous newspaper stories about Emma, or more recently a proliferation of short online biographies, are likewise related to this genealogy. Geoffrey Dutton's novel, Queen Emma of the South Seas, though much less indebted to Robson and based on his own research, remains largely in tune with these earlier depictions of Emma. Dutton's Queen Emma comes to success less through acumen and strategy, but because she knows that "a woman has power through her womanliness and her body" (Dutton 1976: 38). Dutton's novel was later produced as the television mini-series Emma: Queen of the South Seas (1988). The Australian-made film starred Barbara Carrera, a Latina soap star, as Emma, and duly emphasised her beauty and sexuality.

Phebe has received less attention from writers, yet her treatment has been in many ways more full and textured than that given to her sister. This is perhaps due not only to differences between their lives, but also because 
those who wrote most about Phebe-Lilian Overell and Margaret Meadwere women, and women who knew Phebe personally. These women still observed Phebe through prisms of difference - particularly shaped by class and race - but they had sensibilities that comprehended some of the peculiar challenges Phebe faced in entering public, commercial and colonial domains. No doubt it also helped that they were uninterested in either Phebe or Emma's sexual lives, while fully understanding that intimate lives - in Phebe's case, with local peoples as well as her family - were critically important in their lives and fortunes.

With such remarkable lives, there is no simple message to be drawn out of Phebe and Emma's stories. The accounts that best capture them entertain their complexity and capture their contradictions, and there have been too few of these stories told. Phebe and Emma had worked to be respectable, and to claim positions in a colonial society ready to refuse or question them. Often the reason was not more than that they were Samoan, or that they were women. Yet despite the disparagement and discrimination their gender and Samoan ancestry made them vulnerable to, both Phebe and Emma lived easily with being "half-castes", with being Samoan, with being women. They embraced their 'aiga and brought them to their new land and lives, when they might easily have left or hidden them. The sisters sang, ate, spoke and lived in Samoan ways, even when it invited the kind of colonial prejudices they were well aware of. They produced and lived with their own understandings of femininity and gender, some of which challenged those that prevailed around them. If so much of what was said and written about the sisters has emphasised their adoption of powerful European ways and culture, which they did fully and convincingly, the sisters were well aware that this was more than balanced, because those who saw them as different would always see them only as Samoan. But the sisters are not so easily described. They were women remarkable for negotiating and crossing between different realms, whether those of Europe, Melanesia and Polynesia, private and public, men and women. Phebe and Emma, weavers of the border.

\section{ACKNOWLEDGEMENTS}

I would like to thank Dr Hugh Laracy, Dr Phyllis Herda, Chris Hilliard, Jenny Salesa and I'uogafa Tuagalu for their help in preparing this essay. I would also like to thank Niall McCulloch for helping with the French and Anselm Hagedorn for his help with the German. 


\section{NOTES}

1. According to Robson (1965), Jonas washed up on the Samoan shore in 1838 as a mere teenager, and returned to Samoa in about 1845. Jonas himself makes no mention of an earlier visit, and counts 18 years in late 1864 (Coe to Secretary of State, MS. 15 September 1864, District of the United States Consul-Apia, II).

2. The details, taken from the Coe family Bible, can be found in Robson (1965:32-33).

3. Emma's Jonas later married in Samoa, to Ida Smitz, in a wedding that brought together Apia's white and half-caste society. There was a "Great procession of decorated buggies. Dr \& Mrs Funk, bridesmaids, Therese Schmitz, Miss Ide, Lottie Volkman, Maggie Betham, Thomas \& Sam Meredith, E.F. Allen, a German Clerk, Moli the King's brother." It was followed by a wedding dance in the Apia public hall (Cusack-Smith, MS. 1895)

4. See, particularly, Barry Rigby (1973), and various materials during March 1876, DUSCA, IV.

5. A shorter but more reliable account can be found in Biskup (1974: 6-20).

6. Festetics de Tolna (1904: 72-79) seems to be the source for this rumour, which is endorsed by Niau (1936: 159-60) and Dutton (1976: 160-61).

7. See Hahl 1938: 87; Parkinson 1907: 28-29, 852. Emma is said to have brought coconuts from Samoa (Dwyer 1938: 24-102).

8. Festetics de Tolna (1904: 71-72) tells some particularly harsh tales of the Queen, unconfirmed by any other sources.

9. See Roberts 1996: 109. The life story of Natalie Ingram (Nati Wahlen) is instructive in the texture of these complicated relations, and offers a unique insight.

10. See, Anon. [George Henry Kingsley and George Robert Charles Herbert, Thirteenth Earl of Pembroke], 1895: 209. The section about a Samoan princess (pp. 226-31) is interpreted by Robson (and following him by Grove-Day and Dutton) as referring to Emma Coe, but there is no clear evidence to back this interpretation.

\section{ABSTRACT}

Emma Coe (1850-1913) and Phebe Coe (1863-1944) were sisters born in Samoa to an American father and a Samoan mother. Raised in Samoa, the sisters went on to live much of their lives in Melanesia, mostly in northern New Guinea. The sisters became prominent in business, planting, colonial society, ethnographic work and public culture. This essay is a biography of the sisters, whose histories were extraordinary, as they made public and commercial lives at a time when few women did or indeed could, and where a mixed-race identity was often made into a burden.

Keywords: Biography, Samoa, women, "mixed-race”, New Guinea

Author contact address: Associate Professor Damon Salesa, Centre for Pacific Studies, University of Auckland, Private Bag 92019, Auckland, New Zealand. Email: d.salesa@auckland.ac.nz 
